\title{
Post-magmatic alteration in eudialyte from the North Qôroq centre, South Greenland
}

\author{
IAN M. COULSON \\ School of Earth Sciences, The University of Birmingham, Edgbaston, Birmingham B15 2TT, England
}

\begin{abstract}
The North Qoroq centre comprises a series of nested nepheline syenite intrusions and forms part of the midlate Proterozoic Gardar province of South Greenland. Within the centre fractionation has produced varied rock types ranging from augite-syenite to lujavrite, a eudialyte microsyenite. Samples of eudialyte from the lujavrites of unit SN1B of the centre show evidence for two-stage alteration. This alteration ranges from slight modification along crystal margins to complete breakdown and replacement by new pseudomorphing phases. Modification to crystal margins is accompanied by increasing $\mathrm{Nb}$ and $\mathrm{Zr}$ contents and is related to metasomatism produced by the intrusion of younger syenite units of the North Q6roq centre. More extensive alteration is as a result of metasomatism followed by lower-temperature supergene alteration. Simplified reactions for this breakdown include eudialyte + metasomatic fluid $=$ allanite + nepheline; eudialyte + metasomatic fluid $=$ titanite + aegirine + møsandrite + wöhlerite; eudialyte + fluid $=$ zirfesite + fluid. Mass balance calculations for altered compared with unaltered samples of lujavrite show that alteration took place at approximately constant volume with an overall increase in $\mathrm{Fe}(+2.41 \mathrm{~g} / 100 \mathrm{~g}), \mathrm{Si}$ and $\mathrm{K}(+0.65$ and $+0.61 \mathrm{~g} /$ $100 \mathrm{~g})$, whilst $\mathrm{Na}(-2.67 \mathrm{~g} / 100 \mathrm{~g})$ and all trace elements, particularly $\mathrm{La}, \mathrm{Y}, \mathrm{Nb}$ and $\mathrm{Zr}(-5.6$ to $-166 \mathrm{~g} /$ $10000 \mathrm{~g}$ ) are lost from the system.
\end{abstract}

KIYYWORDS: eudialyte, zirfesite, alteration, metasomatism, lujavrite, Igaliko, Gardar, Greenland.

\section{Introduction}

The North Qôroq centre comprises a series of nested nepheline syenite intrusions and forms part of the Igaliko complex in the mid-late Proterozoic Gardar province of South Greenland (Upton and Emeleus, 1987). The ficld rclationships and petrography of the centre are described by Emeleus and Harry (1970). Within unit SNIB of the centre, several large irregular shaped bodies of lujavrite have been found and are described by Coulson and Chambers (1996). This rock type, a cudialyte microsyenite, is only found in three of the Gardar intrusions and is thought to have formed as a result of accumulation of residual nepheline syenitic magma underneath large countryrock xenoliths (cf. Jones and Larsen, 1985).

Exotic light rare-earth element ( $L R E E)$-minerals and $L R E E$-bearing phases, such as eudialyte, are a major feature of alkaline and agpaitic provinces (e.g. Lovozero, Kola Peninsula), and occur with many unusual minerals such as møsandrite, wöhlerite and nacareniobsite (Vlasov et al., 1966; Mellini and
Merlino, 1979; Petersen et al., 1989; Khomyakov, 1990; Jones et al., 1996). This paper presents new evidence for two-stage alteration of eudialyte from the North Qôroq centre.

\section{Description}

The samples of eudialyte studied are from one of the largest units within the North Qoroq centre. This unit shows extreme effects of fractional crystallization with a marginal augite syenite and a peralkaline (agpaitic) core of lujavrite. The unit has undergone partial auto-metasomatism and metasomatism by later syenite units of the North Qorroq centre and the other Igaliko intrusions (Coulson and Chambers, 1996).

\section{Eudialyte}

Eudialyte $\left(\mathrm{Na}_{3}(\mathrm{Ca}, R E E)_{2}(\mathrm{Fe}, \mathrm{Mn}) \mathrm{Zr}\left(\mathrm{Si}_{3} \mathrm{O}_{9}\right)_{2}\right.$ $(\mathrm{OH}, \mathrm{Cl}, \mathrm{F}))$ was identified in several rock types in North Qôroq including sodalite syenite, lujavrite, 


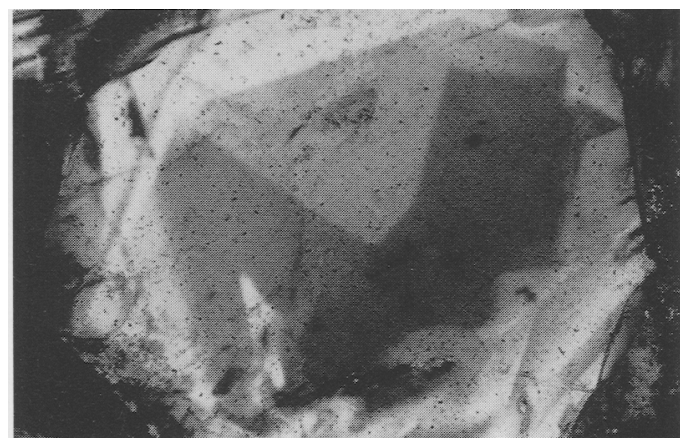

FIG. 1. Photomicrograph of an unaltered eudialyte grain from evolved lujavrite sample (DAR23) under crossed polars. Field of view is $1 \mathrm{~mm}$.

late-stage pegmatite and metasomatized syenite. In the lujavrite eudialyte can reach modal abundances of up to $20 \%$ occurring as idiomorphic $(\sim 1 \mathrm{~mm})$ crystals. Whereas, in alkali-metasomatized nepheline syenites it occurs in close association with sodalite as large $(>2 \mathrm{~mm})$ interstitial, poikiloblastic grains. Representative analyses of eudialyte from North Qôroq, and for comparison, from the adjacent South Qôroq centre are presented in Table 1. The analyses have been recalculated on the basis of 18.5 atoms of oxygen (equivalent to $19 \mathrm{O}, \mathrm{OH}, \mathrm{Cl}, \mathrm{F}$ ). The composition of the eudialyte is more $\mathrm{Na}$ - than $\mathrm{Ca}$ rich and as the mineral is optically positive can be termed eudialyte s.s. as opposed to the Ca-rich endmember of the series, eucolite (Brøgger, 1890; Bollingberg et al., 1983; Deer et al., 1992). This is comparable with eudialyte from the South Qorroq centre.

The larger grains of eudialyte exhibit hour-glass or concentric zoning (Fig. 1) which has been related to variation in minor element content, particularly $\mathrm{Ce}$ (REE) and Mn (Coulson and Chambers, 1996). This zoning is also visible using back-scattered electron imagery (BSEI, Fig. 2). Smaller eudialyte crystals and the margins of larger grains show more irregular zonation patterns and often resorbtion (see Fig. 2). Coulson and Chambers (1996) proposed that this complex zoning reflects primary magmatic crystallization, overprinted by metasomatic activity.

Chemical variation associated with oscillatory zonation is weakly defined, but there is a slight increase in $\mathrm{Ca}, R E E$ and $\mathrm{Mn}$ towards the rim, whereas $\mathrm{Na}, \mathrm{Si}$ and $\mathrm{Fe}$ decrease. Substitutions within North Qôroq eudialyte are small, with only minor systematic changes in $\mathrm{Na}, \mathrm{Ca}, \mathrm{Si}$ and $R E E$. The $\mathrm{Si}$ shows a negative correlation with $\mathrm{Ca}$ and $R E E$, and is positively correlated with $\mathrm{Na}$. At crystal margins extensive variation involving $\mathrm{Nb}$ and $\mathrm{Zr}$ occurs.

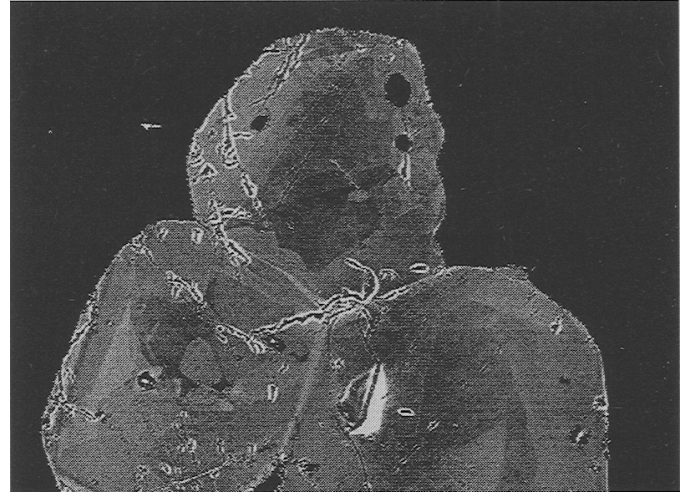

FIG. 2. Back-scattered electron image (BSEI) illustrating subtle but complex zonation in eudialyte from lujavrite sample (DAR24). Note irregular resorbtion near crystal margins. Field of view is $750 \mu \mathrm{m}$.

Niobium reaches 6 wt. \% $\mathrm{Nb}_{2} \mathrm{O}_{5}$ whereas $\mathrm{Zr}$ values are much lower than the uniformly high values $\left(11-12 \% \mathrm{ZrO}_{2}\right)$ of the crystal interiors. This erratic variation has been related to metasomatic reactions at the grain margin, and implies that the fluid was capable of mobilizing $\mathrm{Nb}$ and $\mathrm{Zr}$ (Coulson and Chambers, 1996).

Due to the difficulty in analysing the middle and heavy $R E E$ using the electron microprobe, mineral separates were obtained and rare earth elements were analysed by inductively coupled plasma spectrometry at Royal Holloway and Bedford New College, University of London, on concentrated lanthanide solutions separated by cation exchange techniques at Birmingham University (after Walsh et al., 1981). The high $\mathrm{Nb}$ and $R E E$ content (Table 2) is reflected in high whole rock values for the sample and eudialyte is seen to be the dominant control of the whole rock $R E E$ profile (see Fig. 3).

\section{Alteration}

The alteration of eudialyte initially takes the form of discolouration along grain boundaries and fractures. This can progress to extensive alteration shown in some examples by resorbtion and modification of crystal margins (Coulson and Chambers, 1996). Ultimately, complete replacement of eudialyte by new pseudomorphing phases occurs. However, it should be stated that entirely altered and unaltered grains can occur in the same thin section (cf. Sørensen, 1962). Figure 4 is a BSEI of secondary phases pseudomorphing eudialyte from the lujavrite within unit SN1B. The diagram also gives the identity (if known) of the pseudomorphing phases. Table 3 shows the chemical composition of some of 
TABLE 1. Representative wavelength dispersive electron microprobe analyses of North and South Qôroq eudialyte

\begin{tabular}{|c|c|c|c|c|c|c|c|c|c|}
\hline $\begin{array}{l}\text { Sample } \\
\text { Unit }\end{array}$ & $\begin{array}{c}\text { DAR23 } \\
\text { Lujavrite } \\
\text { SN1B }\end{array}$ & $\begin{array}{c}\text { DAR24 } \\
\text { Lujavrite } \\
\text { SN1B }\end{array}$ & $\begin{array}{c}\text { DAR24 } \\
\text { Lujavrite } \\
\text { SN1B }\end{array}$ & $\begin{array}{c}\text { DAR26 } \\
\text { Lujavrite } \\
\text { SN1B }\end{array}$ & $\begin{array}{c}\text { DAR26 } \\
\text { Lujavrite } \\
\text { SN1B }\end{array}$ & $\begin{array}{c}\text { GGU59661 } \\
\text { Pegmatite } \\
\text { S. Qôroq }\end{array}$ & $\begin{array}{c}\text { GGU59661 } \\
\text { Pegmatite } \\
\text { S. Qôroq }\end{array}$ & $\begin{array}{c}\text { GGU59663 } \\
\text { Pegmatite } \\
\text { S. Qôroq }\end{array}$ & $\begin{array}{c}\text { GGU59663 } \\
\text { Pegmatite } \\
\text { S. Qôroq }\end{array}$ \\
\hline \multicolumn{10}{|c|}{ Oxide wt.\% } \\
\hline $\mathrm{SiO}_{2}$ & 50.264 & 47.872 & 47.979 & 50.101 & 51.718 & 47.590 & 47.808 & 46.362 & 45.708 \\
\hline $\mathrm{TiO}_{2}$ & 0.123 & n.d. & n.d. & 0.140 & 0.145 & n.d. & n.d. & 0.088 & 0.113 \\
\hline $\mathrm{ZrO}_{2}$ & 11.998 & 12.072 & 11.687 & $\begin{array}{l}0.140 \\
11.937\end{array}$ & 12.836 & 11.626 & 11.702 & 11.687 & 11.379 \\
\hline $\mathrm{HfO}_{2}$ & 0.258 & n.d. & n.d. & 0.184 & 0.265 & n.d. & n.d. & 0.226 & 0.267 \\
\hline $\mathrm{Nb}_{2} \mathrm{O}_{5}$ & 1.445 & 1.529 & 1.545 & 1.450 & 0.713 & 1.944 & 1.413 & 2.479 & 2.994 \\
\hline $\mathrm{Al}_{2} \mathrm{O}_{3}$ & 0.295 & n.d. & n.d. & 0.208 & 0.155 & n.d. & n.d. & 0.163 & 0.142 \\
\hline $\mathrm{Y}_{2} \mathrm{O}_{3}$ & 0.477 & 0.382 & 0.439 & 0.434 & 0.467 & 0.283 & 0.324 & 0.305 & 0.382 \\
\hline $\mathrm{La}_{2} \mathrm{O}_{3}$ & 0.611 & 0.526 & 0.579 & 0.629 & 0.388 & 0.348 & 0.327 & 0.616 & 0.803 \\
\hline $\mathrm{Ce}_{2} \mathrm{O}_{3}$ & 1.121 & 0.972 & 1.081 & 1.236 & 0.701 & 0.853 & 0.847 & 1.197 & 1.393 \\
\hline $\mathrm{Pr}_{2} \mathrm{O}_{3}$ & 0.086 & 0.058 & 0.049 & 0.182 & 0.070 & 0.120 & 0.000 & 0.312 & 0.130 \\
\hline $\mathrm{Nd}_{2} \mathrm{O}_{3}$ & 0.444 & 0.319 & 0.352 & 0.439 & 0.372 & 0.271 & 0.262 & 0.378 & 0.463 \\
\hline $\mathrm{Sm}_{2} \mathrm{O}_{3}$ & n.d. & n.d. & n.d. & n.d. & n.d. & n.d. & n.d. & 0.246 & 0.095 \\
\hline $\mathrm{FeO}$ & 6.531 & 5.827 & 6.172 & 6.385 & 6.218 & 6.525 & 6.620 & 6.103 & 6.093 \\
\hline $\mathrm{MnO}$ & 1.425 & 1.328 & 1.421 & 1.427 & 1.205 & 1.488 & 1.322 & 2.169 & 2.466 \\
\hline $\mathrm{CaO}$ & 10.584 & 11.004 & 10.799 & 11.012 & 10.595 & 11.392 & 11.733 & 11.661 & 11.518 \\
\hline $\mathrm{Na}_{2} \mathrm{O}$ & 10.250 & 11.871 & 11.625 & 9.703 & 9.407 & 12.116 & 11.941 & 11.328 & 11.066 \\
\hline $\mathrm{K}_{2} \mathrm{O}$ & 0.266 & 0.187 & 0.164 & 0.193 & 0.201 & 0.149 & 0.279 & 0.233 & 0.254 \\
\hline SrO & 0.025 & n.d. & n.d. & 0.063 & 0.082 & n.d. & n.d. & 0.141 & 0.083 \\
\hline $\mathrm{Cl}$ & 1.576 & 1.443 & 1.441 & 1.497 & 1.553 & 1.230 & 1.287 & 1.342 & 1.243 \\
\hline$-\mathrm{O} \equiv \mathrm{Cl}$ & 0.356 & 0.326 & 0.325 & 0.338 & 0.350 & 0.278 & 0.290 & 0.303 & 0.280 \\
\hline Total & 97.429 & 95.064 & 95.008 & 96.882 & 96.741 & 95.657 & 95.575 & 96.733 & 96.312 \\
\hline O & 18.5 & 18.5 & 18.5 & 18.5 & 18.5 & 18.5 & 18.5 & 18.5 & 18.5 \\
\hline $\mathrm{Si}$ & 6.567 & 6.326 & 6.345 & 6.546 & 6.757 & 6.263 & 6.288 & 6.166 & 6.121 \\
\hline $\mathrm{Al}$ & 0.049 & - & - & 0.033 & 0.032 & - & - & 0.026 & 0.023 \\
\hline $\mathrm{Ti}$ & 0.012 & - & - & 0.014 & 0.019 & -_ & - & 0.010 & 0.012 \\
\hline $\mathrm{Zr}$ & 0.764 & 0.778 & 0.754 & 0.761 & 0.818 & 0.746 & 0.751 & 0.758 & 0.743 \\
\hline $\mathrm{Hf}$ & 0.011 & - & - & 0.007 & 0.013 & - & - & 0.009 & 0.009 \\
\hline $\mathrm{Nb}$ & 0.085 & 0.092 & 0.093 & 0.086 & 0.042 & 0.116 & 0.084 & 0.149 & 0.181 \\
\hline $\mathrm{Fe}$ & 0.714 & 0.644 & 0.683 & 0.698 & 0.679 & 0.718 & 0.728 & 0.679 & 0.683 \\
\hline Mn & 0.158 & 0.149 & 0.159 & 0.158 & 0.133 & 0.166 & 0.147 & 0.244 & 0.279 \\
\hline $\mathrm{Na}$ & 2.597 & 3.042 & 2.980 & 2.458 & 2.383 & 3.091 & 3.045 & 2.921 & 2.873 \\
\hline $\mathrm{Y}$ & 0.033 & 0.027 & 0.031 & 0.030 & 0.032 & 0.019 & 0.022 & 0.021 & 0.027 \\
\hline La & 0.029 & 0.025 & 0.028 & 0.030 & 0.019 & 0.017 & 0.016 & 0.030 & 0.040 \\
\hline $\mathrm{Ce}$ & 0.054 & 0.047 & 0.053 & 0.059 & 0.034 & 0.041 & 0.041 & 0.058 & 0.068 \\
\hline $\mathrm{Pr}$ & 0.004 & 0.003 & 0.002 & 0.009 & 0.003 & 0.006 & 0.000 & 0.016 & 0.007 \\
\hline $\mathrm{Nd}$ & 0.021 & 0.015 & 0.017 & 0.020 & 0.017 & 0.013 & 0.013 & 0.018 & 0.022 \\
\hline $\mathrm{Ca}$ & 1.482 & 1.558 & 1.531 & 1.542 & 1.483 & 1.607 & 1.653 & 1.662 & 1.652 \\
\hline $\mathrm{K}$ & 0.044 & 0.031 & 0.027 & 0.032 & 0.034 & 0.025 & 0.047 & 0.040 & 0.044 \\
\hline $\mathrm{Sr}$ & 0.002 & - & - & 0.005 & 0.008 & - & - & 0.012 & 0.010 \\
\hline $\mathrm{Cl}$ & 0.349 & 0.323 & 0.323 & 0.331 & 0.344 & 0.275 & 0.287 & 0.303 & 0.282 \\
\hline$\Sigma$ & 12.975 & 13.059 & 13.024 & 12,819 & 12.851 & 13.101 & 13.121 & 13.122 & 13.077 \\
\hline
\end{tabular}

Note: n.d. $=$ not determined, total $\mathrm{Fe}$ as $\mathrm{FeO}$

Mineral chemistry was determined using a Cameca Camebax electron microprobe at the University of Edinburgh.

Wavelength-dispersion operating conditions were: accelerating voltage $20 \mathrm{kV}$, beam current $20 \mathrm{nA}$, a rastered beam covering $12 \mathrm{~mm} \times 12.5 \mathrm{~mm}$. Na was analysed first to minimize decay artefacts.

Synthetic silicate glasses made at the University of Edinburgh were used as standards for REE.

$\mathrm{La}, \mathrm{Ce}, \mathrm{Nd}$ and $\mathrm{Y}$ were analysed using $\mathrm{L} \alpha$ lines, whereas, for $\operatorname{Pr}$ and $\mathrm{Sm}, \mathrm{L} \beta$ was used. Data reduction was accomplished using PAP correction procedures. Details are presented in Coulson and Chambers (1996). 
TABLE 2. Whole rock selected trace element analyses

\begin{tabular}{lccccc}
\hline Sample & $\begin{array}{c}\text { DAR24 } \\
\text { Lujavrite } \\
\text { SN1B }\end{array}$ & $\begin{array}{c}\text { DAR24 } \\
\text { Eudialyte } \\
\text { SN1B }\end{array}$ & $\begin{array}{c}\text { DAR23 } \\
\text { Lujavrite } \\
\text { SN1B }\end{array}$ & $\begin{array}{c}\text { DAR25 } \\
\text { Lujavrite } \\
\text { SN1B }\end{array}$ & $\begin{array}{c}\text { GGU5966 } \\
\text { Pegmatite } \\
\text { S. Qroq }\end{array}$ \\
\hline (ppm) & & & & & \\
La & 316.95 & 5115.4 & 124.57 & 478.95 & 366.92 \\
$\mathrm{Ce}$ & 606.96 & 9737.2 & 284.07 & 867.72 & 741.76 \\
$\mathrm{Pr}$ & 59.15 & 916.9 & 30.65 & 82.74 & 70.97 \\
$\mathrm{Nd}$ & 173.6 & 2667 & 94.7 & 238.1 & 200.5 \\
$\mathrm{Sm}$ & 32.3 & 394.4 & 15.89 & 42.77 & 33.02 \\
Eu & 3.18 & 53 & 1.51 & 3.59 & 4.81 \\
Gd & 32.98 & 393 & 12.89 & 40.61 & 32.58 \\
$\mathrm{Dy}$ & 41.89 & 558.1 & 11.6 & 47.56 & 42.87 \\
$\mathrm{Ho}$ & 10.72 & 131.7 & 2.59 & 12.05 & 11.02 \\
$\mathrm{Er}$ & 30.09 & 364.1 & 6.29 & 34.19 & 32.35 \\
$\mathrm{Yb}$ & 34.49 & 413.6 & 6.76 & 39.99 & 34.58 \\
$\mathrm{Lu}$ & 5.28 & 62.1 & 1.04 & 6.36 & 5.04 \\
& & & & & 392.4 \\
$\mathrm{Y}$ & 423.8 & - & 79.2 & 572.9 & 3657 \\
$\mathrm{Zr}$ & 9121 & - & 1171 & 17856 & 1686.7 \\
$\mathrm{Nb}$ & 1070.4 & - & 267.5 & 2071.7 & \\
\hline
\end{tabular}

Note: REE were analysed by ICP-AES at Royal Holloway, University of London, see text for details.

$\mathrm{Y}, \mathrm{Zr}$ and $\mathrm{Nb}$ were analysed by XRF techniques at The University of Birmingham. Powdered samples were pressed into pellets and analysed using a Philips PW1400 automated spectrometer. Detailed procedures are available on request.

these secondary minerals, which include, zircon, allanite-(Ce), aegirine, nepheline, natrolite, titanite, several $R E E$-bearing silicates of the rinkite, møsandrite and wöhlerite series and an unidentified Nb-silicate phase (Table 3, analysis No. 2). Zirfesite has tentatively been identified (Table 3 , analysis Nos 6 and 7), which contrasts with the nearby Ilímaussaq intrusion where it is not seen (Sørensen, 1962).

The zircon is enriched in $R E E$ and can contain up to 5 wt.\% $\mathrm{Y}_{2} \mathrm{O}_{3}$, whilst the CaTiZr-silicates contain similar abundances of $R E E$ to eudialyte and may have been formed by fluorination $\left(\mathrm{CaF}_{2}\right)$ of eudialyte (with coupled loss of $\mathrm{Cl}, \mathrm{Zr}$ and $\left.\mathrm{SiO}_{2}\right)$. Allanite-(Ce), in contrast, contains much higher abundances of $R E E$ than eudialyte and the other phases present. It occupies only a very minor amount of the original crystal space and can therefore be identified as the major repository for the $R E E$ as the eudialyte altered, with minor amounts going into the titanite and other silicate minerals. The $\mathrm{Zr}$ from the original eudialyte seems to have followed a similar pattern with the bulk of this forming the minor zircon and zirfesite patches. Likewise $\mathrm{Nb}$ is incorporated into the unidentified $\mathrm{Nb}$-silicate phase and possibly wöhlerite.
The remaining $\mathrm{Na}, \mathrm{Ca}, \mathrm{Fe}$ and $\mathrm{Si}$ from the eudialyte are equally distributed throughout the replacement zone and have been included in nepheline, natrolite, aegirine and the other silicates.

\section{Discussion}

Previous work has shown that eudialyte is susceptible to the action of hydrothermal and surface water (e.g. Ussing, 1911), with the spectrum of alteration products having intermediate chemical compositions between eudialyte and zirfesite, the end product of eudialyte alteration under hypergene conditions (Deer et al., 1986). The destruction of eudialyte is accomplished by the loss of $\mathrm{Na}$ and $\mathrm{Cl}$ and the introduction of water, and if extensive, the loss of $\mathrm{SiO}_{2}$. This alteration is also accompanied by increasing $\mathrm{Zr}, \mathrm{Fe}$ and $\mathrm{Nb}$ contents (Vlasov et al., 1966).

Several pseudomorphs after eudialyte have been reported in the literature. In Ilímaussaq, secondary minerals after eudialyte include catapleiite, neptunite, aegirine, britholite, monazite, muscovite, biotite, zircon and minor amounts of fluorite, zeolites and sometimes analcite (Boggild, 1953; Sørensen, 1962), 

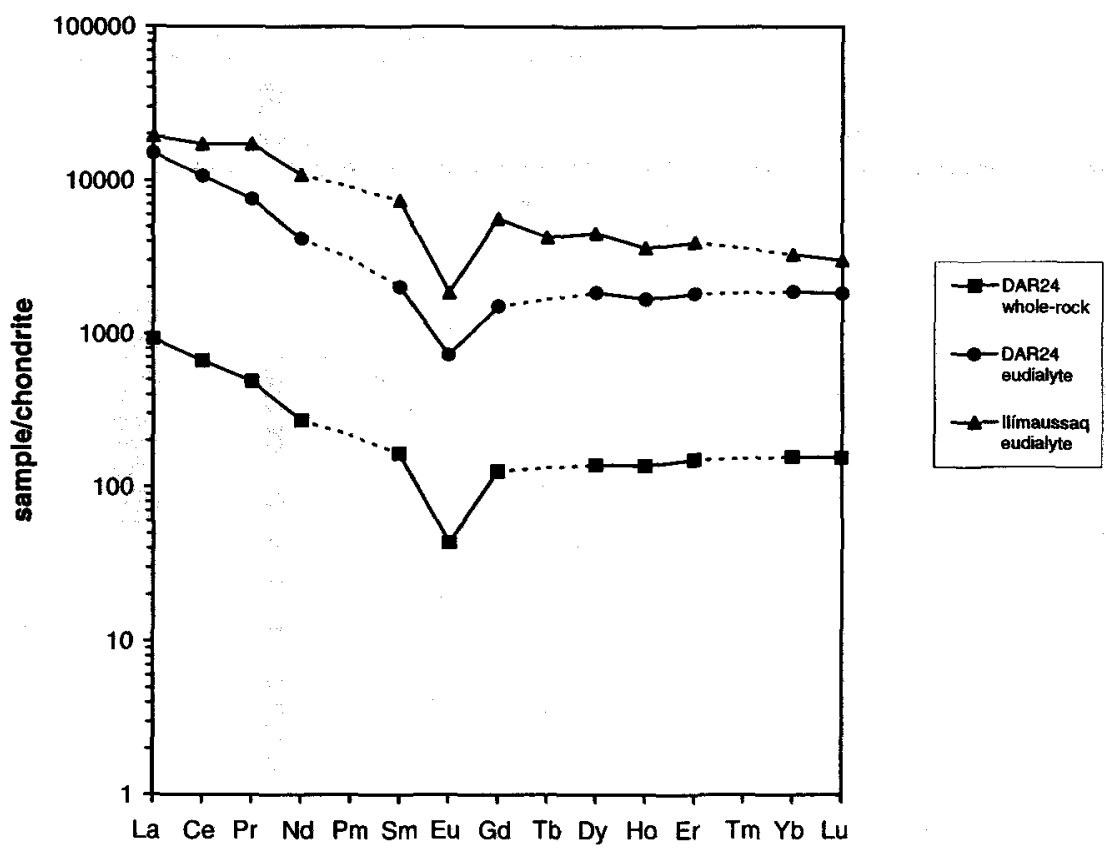

FIG. 3. Chondrite-normalized rare earth element $(R E E)$ patterns for eudialyte from the lujavrite within unit SN1B, with corresponding whole rock pattern. For comparison the $R E E$ pattern of eudialyte from llímaussaq is included (data from Fryer and Edgar, 1977). Chondritic abundances are those of Wakita et al. (1971).

whilst eudialyte relics from Khibina (Dorfman et al., 1963) are present as barsanovite $(\mathrm{Na}, \mathrm{Ca}, R E)_{9}$ $(\mathrm{Mn}, \mathrm{Fe})_{2}(\mathrm{Zr}, \mathrm{Nb})_{2} \mathrm{Si}_{12}(\mathrm{O}, \mathrm{Cl})_{37}$. This appears in rocks in which the nepheline has been cancrinitized and the microcline albitized.

The above description indicates that North Qôroq eudialyte has undergone at least two stages of alteration; the first metasomatic (moderately hightemperature) and the second low-temperature supergene alteration. The high temperature reaction that can be deduced from the observed minerals and from their textures are not well constrained. They include, however, simplified reactions of the form: (1) eudialyte + metasomatic fluid $=$ allanite + nepheline; and (2) eudialyte + metasomatic fluid $=$ titanite + aegirine + møsandrite + wöhlerite.

Depending on the eudialyte compositions and the prevailing $f_{\mathrm{O}_{2}}$ conditions, eudialyte decomposition occurs at temperatures below $800^{\circ} \mathrm{C}$, forming nepheline and allanite, or titanite (Ahmed and MacKenzie, 1978). The two reactions above contain all the major constituents in eudialyte pseudomorphs from the North Qôroq centre. Allanite is stable at up to $\sim 750-800^{\circ} \mathrm{C}$ (Deer et al., 1986; Burt, 1989), and therefore can only have formed below this temperature range, probably as a result of auto-metasomatism within the volatile-rich lujavrite as it cooled. The influx of $\mathrm{K}$ and $\mathrm{Al}$ from the fluid required for the formation of allanite possibly came from the breakdown of biotite in the rock, or albitization of feldspars (Rae et al., 1996).

This alteration is followed by low-temperature fluid interaction (supergene) with the continued decomposition of the remaining eudialyte into the mineral zirfesite $\left(\mathrm{Fe}_{2} \mathrm{Zr}\left(\mathrm{SiO}_{2}\right)_{2}(\mathrm{OH})\right)$. This is also likely to have been responsible for the discolouration along crystal edges and fractures. A simplified reaction of the form: eudialyte + fluid $=$ zirfesite + fluid is likely to have occurred.

In an attempt to define the alteration of the eudialyte-bearing sample more rigorously, the whole rock composition was compared with an unaltered parent using Gresens' equation for mass balance (Gresens, 1967). This work forms part of a larger study (Coulson, in prep.) defining the metasomatic alteration in the North Qôroq centre. Details of the calculations and methodology used are available from the author and will be presented in a later publication.

Gresens' equation is a simple way of relating change in weight fractions of any given component in a rock to the change in density of the rock, so 


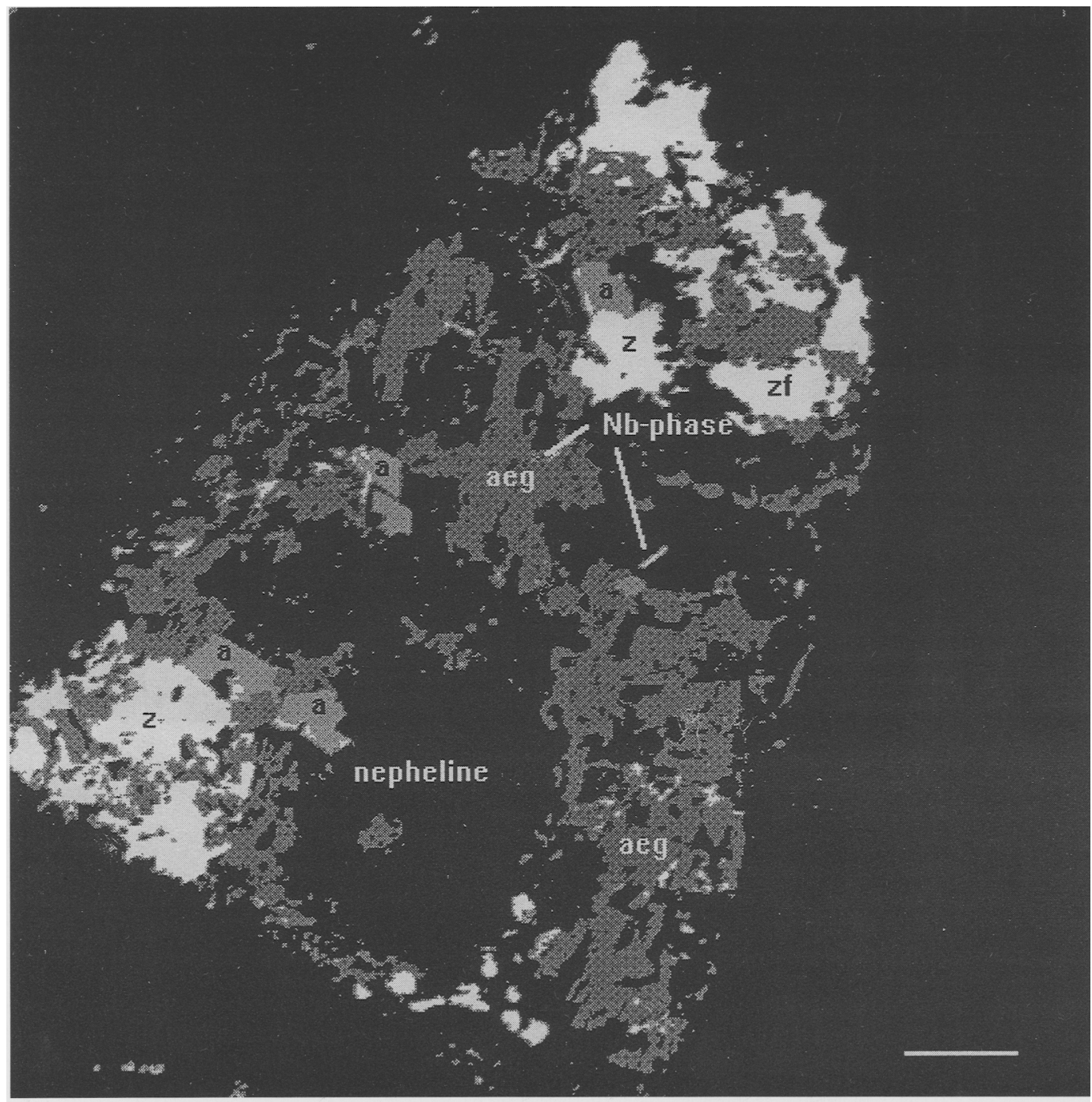

FIG. 4. BSEI of alteration products pseudomorphing eudialyte from lujavrite sample DAR23. $z=z i r c o n, z f=$ zirfesite, $\mathrm{a}=$ allanite, $\mathrm{aeg}=$ aegirine. Scale bar represents $100 \mu \mathrm{m}$.

allowing an estimate of volume change during metasomatism to be made:

$$
\mathrm{X} n=100\left[\mathrm{Fv}\left(\rho^{\mathrm{B}} / \rho^{\mathrm{A}}\right) \mathrm{X} n^{\mathrm{B}}-\mathrm{X} n^{\mathrm{A}}\right]
$$

where $\mathrm{X} n=$ the gain or loss of element $n$ in producing metasomatic rock $B$ from parent rock $A$; $\mathrm{Fv}=$ the volume factor, defined as the ratio between the final and initial volumes (i.e. $\mathrm{V}_{\mathrm{B}} / \mathrm{V}_{\mathrm{A}}$ ); $\mathrm{X} n^{\mathrm{A}},{ }^{\mathrm{B}}=$ the weight fractions of component $n$ in the parent and metasomatic rock and $\rho^{\mathrm{A}, \mathrm{B}}=$ the specific gravity of the parent and metasomatic rock.
Figure 5 shows the composition-volume plot for the metasomatized sample DAR23 against a protolith (the average of 2 unaltered lujavrites from the same unit). The $\mathrm{X} n-\mathrm{Fv}_{\mathrm{v}}$ values were calculated for each element at set volume factors of $0.6,0.8,1.0,1.2$ and 1.4 , corresponding to a range in volume change from $60 \%$ of the original volume up to $140 \%$ (Table 4). Where the individual lines cut the $\mathrm{Xn}$ axis at 0 indicates the element was immobile. If several of the lines crossed the gain-loss zero line at the same value of Fv, Gresens proposed that this 'clustering' can 
TABLE 3. Representative wavelength dispersive electron microprobe analyses of North Qôroq eudialyte alteration products

\begin{tabular}{|c|c|c|c|c|c|c|c|c|c|}
\hline Sample & $\begin{array}{l}\text { DAR23 } \\
\text { Allanite }\end{array}$ & $\begin{array}{c}\text { DAR23 } \\
\text { Nb-silicate }\end{array}$ & $\begin{array}{c}\text { DAR23 } \\
\text { Aegirine }\end{array}$ & $\begin{array}{c}\text { DAR23 } \\
\text { Nepheline }\end{array}$ & $\begin{array}{l}\text { DAR23 } \\
\text { Y-rich } \\
\text { zircon }\end{array}$ & $\begin{array}{c}\text { DAR23 } \\
\text { Zirfesite }\end{array}$ & $\begin{array}{l}\text { DAR23 } \\
\text { Zirfesite }\end{array}$ & $\begin{array}{l}\text { Lovozero } \\
\text { Zirfesite }^{\dagger} \\
\text { Lujavrite }^{-}\end{array}$ & $\begin{array}{l}\text { DAR23 } \\
\text { CaTiZr } \\
\text { silicate }\end{array}$ \\
\hline \multicolumn{10}{|c|}{ Oxide wt. $\%$} \\
\hline $\mathrm{SiO}_{2}$ & 33.10 & 32.17 & 51.35 & 44.37 & 31.69 & 26.08 & 22.99 & 21.27 & 30.18 \\
\hline $\mathrm{ZrO}_{2}$ & 0.11 & 0.60 & 0.29 & 0.04 & 59.27 & 44.11 & 22.75 & 30.96 & 2.55 \\
\hline $\mathrm{HfO}_{2}$ & n.d. & n.d. & n.d. & n.d. & n.d. & 1.43 & 0.50 & n.d. & n.d. \\
\hline $\mathrm{TiO}_{2}$ & n.d. & n.d. & n.d. & n.d. & n.d. & n.d. & n.d. & 0.96 & 8.47 \\
\hline $\mathrm{Al}_{2} \mathrm{O}_{3}$ & 15.09 & 8.55 & 1.65 & 31.28 & n.d. & n.d. & n.d. & 1.63 & 0.05 \\
\hline $\mathrm{Y}_{2} \mathrm{O}_{3}$ & 0.00 & 0.11 & 0.00 & n.d. & 5.29 & 3.33 & 0.44 & n.d. & 1.67 \\
\hline $\mathrm{La}_{2} \mathrm{O}_{3}$ & 5.64 & 0.02 & 0.00 & n.d. & 0.00 & 0.10 & 0.13 & n.d. & 1.27 \\
\hline $\mathrm{Ce}_{2} \mathrm{O}_{3}$ & 10.64 & 0.14 & 0.07 & n.d. & 0.08 & 0.33 & 0.85 & $* 2.12$ & 3.49 \\
\hline $\mathrm{Pr}_{2} \mathrm{O}_{3}$ & n.d. & n.d. & n.d. & n.d. & 0.03 & n.d. & n.d. & n.d. & n.d. \\
\hline $\mathrm{Nd}_{2} \mathrm{O}_{3}$ & 2.58 & 0.03 & 0.44 & n.d. & 0.12 & 0.12 & 0.35 & n.d. & 1.50 \\
\hline $\mathrm{Sm}_{2} \mathrm{O}_{3}$ & 0.10 & 0.13 & 0.00 & n.d. & 0.04 & n.d. & n.d. & n.d. & n.d. \\
\hline $\mathrm{FeO}$ & 15.24 & 11.02 & 0.00 & 1.17 & n.d. & n.d. & n.d. & n.d. & n.d. \\
\hline $\mathrm{Fe}_{2} \mathrm{O}_{3}$ & n.d. & n.d. & 32.81 & n.d. & 0.35 & 7.03 & 22.60 & 14.27 & 0.62 \\
\hline $\mathrm{MnO}$ & 1.96 & 0.28 & 0.43 & 0.03 & n.d. & n.d. & n.d. & 0.24 & 0.42 \\
\hline $\mathrm{Nb}_{2} \mathrm{O}_{5}$ & 0.00 & 17.65 & 0.19 & n.d. & 0.00 & n.d. & n.d. & 2.40 & 1.57 \\
\hline $\mathrm{CaO}$ & 9.61 & 5.35 & 0.64 & 0.03 & n.d. & n.d. & n.d. & 0.14 & 32.98 \\
\hline $\mathrm{Na}_{2} \mathrm{O}$ & 3.28 & 7.15 & 13.57 & 16.47 & n.d. & n.d. & n.d. & n.d. & 6.67 \\
\hline $\mathrm{K}_{2} \mathrm{O}$ & n.d. & n.d. & n.d. & 5.14 & n.d. & n.d. & n.d. & 0.21 & 0.00 \\
\hline $\mathrm{SO}_{3}$ & n.d. & n.d. & n.d. & 0.03 & n.d. & n.d. & n.d. & n.d. & n.d. \\
\hline $\mathrm{Cl}$ & n.d. & n.d. & n.d. & 0.02 & 1.29 & n.d. & n.d. & n.d. & 0.02 \\
\hline F & n.d. & n.d. & n.d. & n.d. & n.d. & n.d. & n.d. & n.d. & 6.14 \\
\hline $\mathrm{H}_{2} \mathrm{O}^{+}$ & n.d. & n.d. & n.d. & n.d. & n.d. & n.d. & n.d. & 9.66 & n.d. \\
\hline $\mathrm{H}_{2} \mathrm{O}^{-}$ & n.d. & n.d. & n.d. & n.d. & n.d. & n.d. & n.d. & 16.17 & n.d. \\
\hline$-\mathrm{O} \equiv \mathrm{F}, \mathrm{Cl}$ & - & - & - & 0.00 & 0.29 & - & - & - & 2.59 \\
\hline Total & 97.34 & 83.19 & 101.44 & 98.57 & 97.86 & 82.53 & 70.59 & 100.11 & 95.01 \\
\hline $\mathrm{O}$ & 13 & 13 & 6 & 16 & 4 & 4 & 4 & 4 & 24 \\
\hline Si & 3.278 & 3.419 & 1.979 & 4.318 & 1.007 & 0.976 & 0.968 & 0.913 & 5.799 \\
\hline $\mathrm{Zr}$ & 0.005 & 0.030 & 0.006 & - & 0.918 & 0.805 & 0.467 & 0.637 & 0.239 \\
\hline $\mathrm{Hf}$ & - & - & - & -. & - & 0.015 & 0.006 & - & - \\
\hline $\mathrm{Ti}$ & - & - & - & - & - & - & - & 0.031 & 1.225 \\
\hline $\mathrm{Al}$ & 1.761 & 1.070 & 0.075 & 3.587 & - & - & - & 0.082 & 0.011 \\
\hline$Y$ & 0.000 & 0.007 & 0.000 & - & 0.089 & 0.066 & 0.010 & - & 0.171 \\
\hline $\mathrm{La}$ & 0.206 & 0.000 & 0.000 & - & 0.000 & - & - & - & 0.090 \\
\hline $\mathrm{Ce}$ & 0.386 & 0.004 & 0.002 & - & 0.001 & 0.004 & 0.013 & 0.033 & 0.246 \\
\hline $\mathrm{Nd}$ & 0.091 & 0.002 & 0.003 & - & 0.001 & - & - & - & 0.103 \\
\hline $\mathrm{Sm}$ & 0.003 & 0.004 & - & - & - & - & - & - & - \\
\hline $\mathrm{Fe}^{2+}$ & 1.262 & 0.979 & 0.000 & 0.095 & - & - & $\ldots$ & - & 0.100 \\
\hline $\mathrm{Fe}^{3+}$ & - & - & 0.952 & - & 0.008 & 0.198 & 0.716 & 0.512 & - \\
\hline $\mathrm{Mn}$ & 0.164 & 0.024 & 0.014 & 0.002 & - & - & - & 0.008 & 0.068 \\
\hline $\mathrm{Nb}$ & 0.000 & 0.847 & 0.008 & - & 0.000 & - & - & 0.005 & 0.136 \\
\hline $\mathrm{Ca}$ & 1.020 & 0.609 & 0.026 & 0.003 & - & - & - & 0.006 & 6.791 \\
\hline $\mathrm{Na}$ & 0.630 & 1.473 & 1.014 & 3.108 & - & - & - & - & 2.484 \\
\hline $\mathrm{K}$ & - & - & - & 0.638 & - & - & - & 0.001 & - \\
\hline$\Sigma$ & 8.808 & 8.468 & 4.000 & 11.751 & 2.024 & 2.064 & 2.186 & 2.228 & 17.463 \\
\hline
\end{tabular}

n.d. = not determined

${ }^{*} \mathrm{Ce}_{2} \mathrm{O}_{3}$ represents $\mathrm{\Sigma} R E_{2} \mathrm{O}_{3}$

$\uparrow$ Zirfesite analysis taken from Vlasov et al. (1966) 


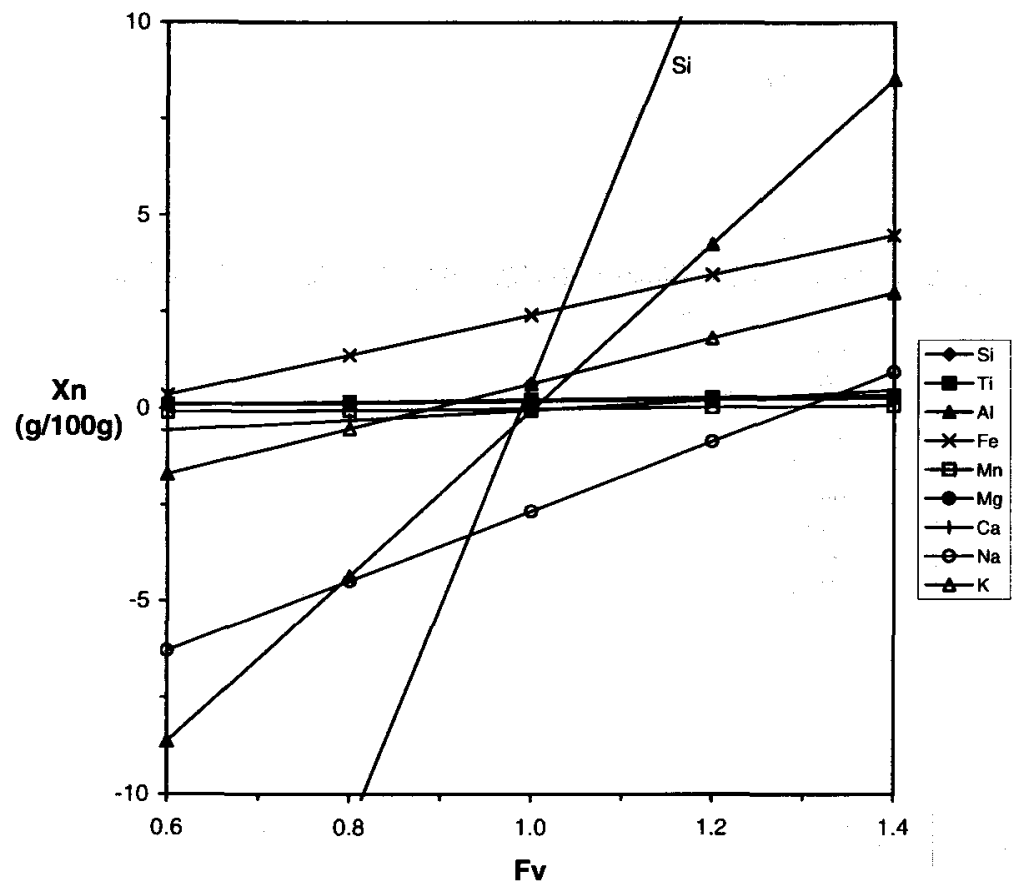

Fig. 5. Composition-volume (Xn-Fv) plot for sample DAR23 against protolith from unit SN1B. Fv values of 0.6, 0.8, 1.0, 1.2 and 1.4 are substituted into Gresens' (1967) equation and corresponding values of Xn are calculated for each component.

indicate that those elements constitute a group of immobile elements and the unique Fv value deduced can be applied to the other mobile elements to calculate the gains and losses. The basis for this is simply that it is unlikely that a group of elements would behave identically if they were all mobile. However, Appleyard and Woolley (1979) and Appleyard (1980) suggest that in some instances elements will behave in an identical fashion and other evidence should be sought in order to confirm this grouping.

It is interesting to note that several of the element lines cut $\mathrm{X} n=0$ at close to $\mathrm{Fv} 1.0$, which corresponds to zero volume change (constant volume). These elements include $\mathrm{Si}, \mathrm{Ca}$ and $\mathrm{Al}$, of which $\mathrm{Al}$ is commonly taken to be immobile during metasoma-

TABLE 4. Calculated Xn-Fv values for sample DAR23 from Gresens' (1967) equation

\begin{tabular}{|c|c|c|c|c|c|c|c|c|c|}
\hline \multirow{2}{*}{\multicolumn{2}{|c|}{$\begin{array}{l}\text { Calculated Xn-Fv } \\
\text { Sample DAR23 } \\
\text { Fv }\end{array}$}} & \multirow[b]{2}{*}{$\mathrm{Ti}$} & \multirow[b]{2}{*}{$\mathrm{Al}$} & \multirow[b]{2}{*}{$\mathrm{Fe}_{\mathbf{T}}$} & \multirow[b]{2}{*}{ Mn } & \multirow[b]{2}{*}{$\mathbf{M g}$} & \multicolumn{3}{|c|}{$\begin{aligned} \text { density protolith } & =2.551 \\
\text { density sample } & =2.556\end{aligned}$} \\
\hline & $\mathrm{Si}$ & & & & & & $\mathrm{Ca}$ & $\mathrm{Na}$ & $\mathrm{K}$ \\
\hline 0.6 & -22.50 & 0.11 & -8.65 & 0.35 & -0.10 & 0.09 & -0.57 & -6.29 & -1.71 \\
\hline 0.8 & -10.93 & 0.17 & -4.35 & 1.38 & -0.05 & 0.13 & -0.31 & -4.48 & -0.53 \\
\hline 1.0 & 0.65 & 0.22 & -0.06 & 2.41 & -0.01 & 0.18 & -0.05 & -2.67 & 0.64 \\
\hline 1.2 & 12.22 & 0.28 & 4.24 & 3.44 & 0.03 & 0.23 & 0.22 & -0.86 & 1.82 \\
\hline 1.4 & 23.79 & 0.34 & 8.54 & 4.47 & 0.07 & 0.27 & 0.48 & 0.94 & 2.99 \\
\hline
\end{tabular}




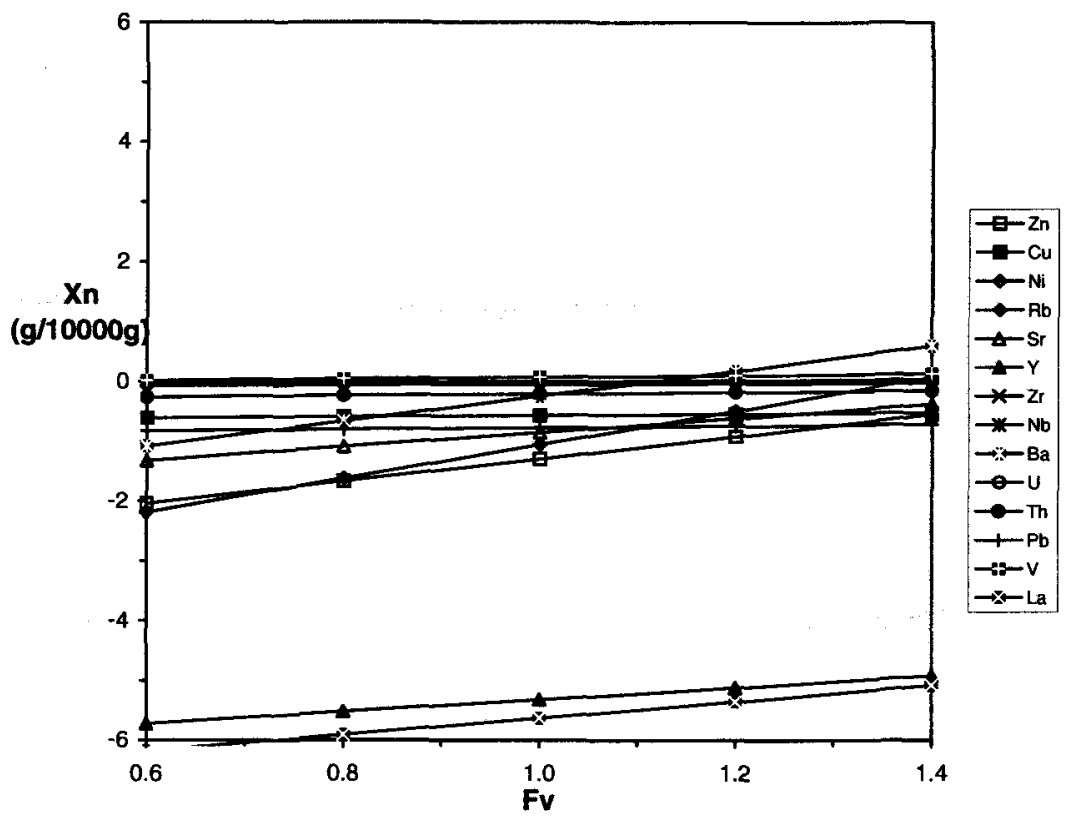

FIG. 6. Corresponding composition-volume (Xn-Fv) plot for trace elements from sample DAR23 against protolith from unit SN1B.

tism of felsic rocks (Rubie, 1982; Rubie and Gunter, 1983). This Fv agrees with petrographic observations of constant volume (i.e. lack of veining, pseudomorphs), and can be taken as a further line of evidence for the accuracy of using this equation as a model for defining metasomatic alteration. The plot shows that at near constant volume there is an increase in $\mathrm{Fe}(+2.41 \mathrm{~g} / 100 \mathrm{~g})$ and a slight increase in $\mathrm{Si}$ and $\mathrm{K}(+0.65$ and $+0.61 \mathrm{~g} / 100 \mathrm{~g})$, whilst $\mathrm{Na}$ is the only significant element to decrease $(-2.67 \mathrm{~g} / 100 \mathrm{~g})$. Figure 6 is the corresponding plot for trace elements. What is noticeable is that all trace elements are lost from the systems (at reasonably realistic volume factors) and that most noticeably $\mathrm{La}, \mathrm{Y}, \mathrm{Nb}$ and $\mathrm{Zr}$ are significantly depleted $(-5.6$ to $-166 \mathrm{~g} / 10000 \mathrm{~g}$ at Fv 1.0). The only element on the plot seen to gain is $\mathrm{Ba}$ and this is only at a volume factor of 1.2 , representative of a volume increase of $20 \%$, which clearly contradicts petrographic evidence. Therefore it can be stated that metasomatism took place at near constant volume with only small gains and losses in major elements (namely increase in $\mathrm{Fe}$, loss of $\mathrm{Na}$ ) and extreme trace element (particularly $R E E, \mathrm{Nb}$ and $\mathrm{Zr}$ ) loss from the sample. This implies that the alteration of eudialyte (the major repository for $\mathrm{Na}$, $R E E, \mathrm{Y}, \mathrm{Zr}$ and $\mathrm{Nb}$ ) took place with most of the constituent elements being lost to the fluid and only Fe being introduced, which was incorporated into the new mineral zirfesite. The remaining quantities of trace elements within the eudialyte went on to make up the allanite and other psuedomorphing phases. One concluding point to note is that metasomatized quartzite xenoliths above the lujavrite are highly enriched in $R E E$ ( $>20,000 \mathrm{ppm}$ whole rock). Presumably this acted as a sink for the products of eudialyte alteration (Rae et al., 1996).

The above whole rock data seem to support the other data (i.e. mineral analyses) that $\mathrm{Na}$ is lost from the North Qôroq eudialyte during alteration. This may explain why other more common alteration products of eudialyte, the complex $\mathrm{Na}-\mathrm{Zr}$-silicates (namely catapleiite, lovozerite and steenstrupine: Sørensen, 1962; Vlasov et al., 1966; Bollingberg et al., 1983) are not present in North Qôroq. North Qôroq fluids are not as peralkaline (persodic) as those at Ilímaussaq and hence these $\mathrm{Na}-\mathrm{Zr}$-rich products will not be observed/preserved.

\section{Conclusions}

Pristine euhedral eudialyte from North Qôroq is a product of residual magmatic crystallization. It is seen to alter readily and, commonly, pseudomorphs after eudialyte are formed by secondary minerals.

This new mineral assemblage has come about as the result of two stages of post-magmatic fluid 
interaction. The first, soon after crystallization, is metasomatic alteration, related to the cooling of the volatile rich magma, or fluids from later intrusions, which produced the high temperature replacement assemblage (e.g. allanite, zircon). The second less aggressive fluid is supergene in origin and lower temperature, which aided the continued decomposition of eudialyte to the mineral zirfesite. This alteration took place at near constant volume with the loss of $\mathrm{Na}$ and trace elements (particularly $R E E$, $\mathrm{Y}, \mathrm{Zr}$ and $\mathrm{Nb}$ ) and only minor introduction of $\mathrm{Fe}$ into the system.

Fresh unaltered grains occur with completely altered eudialyte in the same thin section, indicating that fluids responsible for this alteration were not pervasive. The elements $\mathrm{Zr}, \mathrm{Nb}, \mathrm{Y}$ and $R E E$ were shown to be mobile in the fluid phase.

\section{Acknowledgements}

Original fieldwork on the North Qôroq centre was supported by the Geological Survey of Denmark and Greenland, and results on Survey material appear by permission of the Director. Research for the current work was carried out during tenure of a postgraduate studentship from NERC. I am grateful to A.D. Chambers for his supervision and introduction to the subject. J.R. Ashworth is thanked for his helpful and constructive comments on an earlier version of the manuscript. This work has benefited from the careful and critical reviews of F. Wall and A. Finch. The assistance of G.L. Hendry (Birmingham), P. Hill and $S$. Kearns (University of Edinburgh) and $S$. James and N. Walsh (Royal Holloway, University of London) with various aspects of analytical work is gratefully acknowledged.

\section{References}

Ahmed, M. and MacKenzie, W.S. (1978) Preliminary report on the synthesis and stability of eudialyte. Progress in Experimental Petrology, Fourth Report 1975-8, 47-9. NERC.

Appleyard, E.C. and Woolley, A.R. (1979) Fenitization: an example of the problems of characterizing mass transfer and volume changes. Chem. Geol., 26, $1-15$.

Appleyard, E.C. (1980) Mass balance computations in metasomatism: Metagabbro/nepheline syenite pegmatite interaction in northern Norway. Contrib. Mineral. Petrol., 73, 131-44.

Bøggild, O.B. (1953) The mineralogy of Greenland. Medd. øm Grønland, 149;3, $251 \mathrm{pp}$.

Bollingberg, H.J., Ure, A.M., Sørensen, I. and Leonardsen, E.S. (1983) Geochemistry of some eudialyte-eucolite specimens and a co-existing catapleiite from Langesund, Norway. Tschermaks
Min. Petr. Mitt., 32, 153-69.

Brøgger, W.C. (1890) Die Mineralien der südnorwegischen Augit- und Nephelin Syenite. Z. Kristallogr., 16, II.

Burt D.M. (1989) Compositional and phase relations among rare earth element minerals. In Geochemistry and Mineralogy of Rare Earth Elements (B.R. Lipin and G.A. McKay, eds). Mineralogical Society of America, Reviews in Mineralogy, 21, 259-307.

Coulson, I.M. and Chambers, A.D. (1996) Patterns of zonation in patterns in rare-earth bearing minerals in nepheline syenites of the North Qôroq centre, South Greenland Can. Mineral., 34(6), (in press).

Deer, W.A, Howie, R.A. and Zussman, J. (1986) RockForming Minerals - Volume $1 B$ Disilicates and Ring Silicates ( 2 nd ed.). Longman Scientific \& Technical, Harlow, England.

Deer, W.A, Howie, R.A. and Zussman, J. (1992) An Introduction to the Rrock-Forming Minerals (2nd ed.). Longman Scientific \& Technical, Harlow, England, $696 \mathrm{pp}$.

Dorfman, M.D., Ilokhim, V.V. and Burova, T.A. (1963) [Barsanovite - a new mineral.] C. R. Acad. Sci., USSR, 153, 1164-67 (in Russian).

Emeleus, C.H. and Harry, W.T. (1970) The Igaliko Nepheline syenite complex: general description. Medd. øm Grønland, 186;3, 115 pp.

Fryer, B.J. and Edgar, A.D. (1977) Significance of rareearth distributions in coexisting minerals of peralkaline undersaturated rocks. Contrib. Mineral. Petrol., 61, 35-48.

Gresens, R.L. (1967) Composition-volume relationships of metasomatism. Chem. Geol., 2, 47-55.

Jones, A.P. and Larsen, L.M. (1985) Geochemistry and $R E E$ minerals of nepheline syenites from the Motzfeldt centre, South Greenland. Amer. Mineral., 70, 1087-100.

Jones, A.P., Wall, F. and Williams, C.T. (eds.) (1996) Rare Earth Minerals: Chemistry, Origin and Ore Deposits. The Mineralogical Society Series 7, Chapman and Hall, London, 372 pp.

Khomyakov, A.P. (1990) Mineralogy of Hyperagpaitic Alkaline Rocks, Science Press, Moscow, 196 pp (in Russian). Translated into English as Khomyakov, A.P. (1995) Mineralogy of Hyperagpaitic Alkaline Rocks, Clarendon Press, Oxford, 233 pp.

Mellini, M. and Merlino, S. (1979) Refinement of the crystal structure of wöhlerite. Tschermaks Min. Petr. Mitt., 26, 109-23.

Petersen, O.V., Rønsbo, J.G. and Leonardsen, E.S. (1989) Nacareniobsite-(Ce), a new mineral species from the Ilímaussaq alkaline complex, South Greenland, and its relation to møsandrite and the rinkite series. Neues Jahrb. Mineral. Mh., 2, 84-96.

Rae, D.A., Coulson, I.M. and Chambers, A.D. (1996) Metasomatism in the North Qôroq centre, South Greenland: apatite chemistry and rare-earth element 
transport. Mineral. Mag., 60, 207-20.

Rubie, D.C. (1982) Mass transfer and volume change during alkali metasomatism at Kisingiri, Western Kenya. Lithos, 15, 99-109.

Rubie, D.C. and Gunter, W.D. (1983) The role of speciation in alkaline igneous fluids during fenite metasomatism. Contrib. Mineral. Petrol., 82, 165-75.

Sørensen, H. (1962) On the occurrence of steenstrupine in the Ilímaussaq massif, southwest Greenland. Medd. фm Gronland, 32;1, 251 pp.

Upton, B.G.J. and Emeleus, C.H. (1987) Mid Proterozoic alkaline magmatism in southern Greenland. In Alkaline Igneous Rocks (J.G. Fitton and B.G.J. Upton, eds.). Spec. Publ. Geol. Soc., London, 30, 449-71.

Ussing, N.V. (1911) Geology of the country around
Julianehaab. Medd. øm Grønland, 38, 376 pp.

Vlasov, K.A., Kuz'menko, M.Z. and Es'kova, E.M. (1966) The Lovozero Alkali Massif. Oliver and Boyd, Edinburgh and London, $627 \mathrm{pp}$.

Watika, H., Rey, P. and Schmitt, R.A. (1971) Abundances of the 14 rare-earth elements and 12 other trace elements in Apollo 12 samples: five igneous and one breccia rocks and four soils. Proc. 2nd Lunar Sci. Conf., pp. 1319-29.

Walsh, J.N., Buckley, F. and Barker, J. (1981) The simultaneous determination of the rare-earth elements in rocks using inductively coupled plasma source spectrometry. Chem. Geol., 33, 141-53.

[Manuscript received 26 February 1996:

revised 2 July 1996] 